\title{
Rhizobium taibaishanense sp. nov., isolated from a root nodule of Kummerowia striata
}

\author{
Li Juan Yao, ${ }^{1}$ Yao Yao Shen, ${ }^{1}$ Jun Peng Zhan, ${ }^{1}$ Wei Xu, ${ }^{1}$ \\ Guang Ling Cui ${ }^{1,2}$ and Ge Hong Wei
}

Correspondence

Ge Hong Wei

weigehong@yahoo.com.cn

\author{
${ }^{1}$ College of Life Sciences, Shaanxi Key Laboratory of Molecular Biology for Agriculture, \\ Northwest A \& F University, Yangling Shaanxi 712100, PR China \\ ${ }^{2}$ Key Laboratory of Protection and Utilization of Biological Resources in Tarim Basin, \\ Xinjiang Production and Construction Group, Alar Xinjiang 843300, PR China
}

The species once assigned to the genus Agrobacterium Conn 1942 are Gram-reaction-negative soil bacteria that were placed in the family Rhizobiaceae of the class Proteobacteria on the basis of their rRNA gene characteristics (Kersters et al., 1973; Woese et al., 1984). Most of these micro-organisms are plant pathogens that cause the formation of crown galls or hairy roots on various plant species, and their classification was once mainly based on their pathogenic properties. According to Young et al. (2001), the 16S rRNA gene sequences of species of the genus Agrobacterium are so similar to those of species of the genus Rhizobium that all Agrobacterium species should be transferred into the genus Rhizobium. Although this

The GenBank accession numbers for the $16 \mathrm{~S}$ rRNA, rec $A$ and $g$ InA gene sequences of strain CCNWSX $0483^{\top}$ are HM776997, HM777002 and H0846353, respectively.

A supplementary table and two supplementary figures are available with the online version of this paper. transfer has largely been accepted, it remains a subject of controversy and debate (Farrand et al., 2003).

Kummerowia is a genus of flowering plants belonging to the subfamily Faboideae of the family Leguminosae. Species of the genus Kummerowia are drought-enduring and can be used as fodder for cattle, as green manure and/ or to prevent soil erosion (Allen \& Allen, 1981). In China, some Kummerowia species are also valued as medicines and are used for the treatment of traumatic injuries with blood stasis, dysentery, icteric hepatitis, sores, carbuncles, furuncles and abscesses (New Medicine College of Jiangsu, 1977). Species of the genus Kummerowia are also being considered for the treatment of menopausal dysfunction, since they are a source of oestrogen (Yoo et al., 2005).

Cui et al. (2010) recently isolated 53 rhizobial strains from the root nodules of Kummerowia striata grown in northwestern China and explored the strains' phenotypes and genetics. Analysis of their $16 \mathrm{~S}$ rRNA gene sequences indicated that four of the strains (CCNWSX $0483^{\mathrm{T}}$, 
CCNWSX 0487, CCNWSX 0481 and CCNWSX 0457) were closely related to Rhizobium vitis, with a mean sequence similarity of $99.3 \%$. In the present study, to verify their taxonomic position, these four strains were further characterized by sequence analyses of the $r e c A$ and $g \ln A$ housekeeping genes, repetitive element PCR fingerprinting (rep-PCR), DNA-DNA hybridization, the determination of cellular fatty acid profiles and numerical taxonomy. In addition, the existence of sym and vir genes in the four strains was checked in PCR-based assays and plant inoculation tests. All of the strains were grown on yeastmannitol agar (YMA; Vincent, 1970) at either $28{ }^{\circ} \mathrm{C}$ or, for temporary storage, $4{ }^{\circ} \mathrm{C}$.

Total genomic DNA, isolated and purified as described by Moulin et al. (2004), was used as PCR template. The universal primers P1/P6 (Tan et al., 1997) were used to amplify the almost-complete 16S rRNA gene sequence (Wang et al., 1998) whereas partial recA and $g \ln A$ gene sequences were determined as described by Gaunt et al. (2001) and Turner \& Young (2000), respectively. All of the sequences were compared with those found by BLAST searching in the NCBI sequence database (Altschul et al., 1990). Sequences were aligned using the CLUSTAL W program (Thompson et al., 1994) before the distances between the sequences were calculated using the maximum composite likelihood method (Tamura et al., 2004), the Kimura two-parameter method (Kimura, 1983) and the methods of Jukes \& Cantor (1969) and Tajima \& Nei (1984). Phylogenetic trees were constructed using the MEGA 4.1 package (Kumar et al., 2008) and the neighbour-joining (Saitou \& Nei, 1987), minimum-evolution (Rzhetsky \& Nei, 1993) and maximum-parsimony methods (Swofford, 1993). The robustness of the tree branches was estimated from bootstrap analysis, with 1000 replications. There were no significant topological differences between the phylogenetic trees created using the three treeing methods. The trees shown (Figs 1 and 2) were inferred by the neighbourjoining method after distance analysis of the aligned sequences according to the maximum composite likelihood model. In the trees for the 16S rRNA gene sequences, strains CCNWSX 0483 ${ }^{\mathrm{T}}$, CCNWSX 0487, CCNWSX 0481 and CCNWSX 0457 formed one tight group within the genus Rhizobium (Fig. 1). The observed 16S rRNA gene sequences of three of these strains were, in fact, identical, and that of the other strain (CCNWSX 0457, isolated in Yangling) differed from these by just $1 \mathrm{bp}$. In terms of their 16S rRNA gene sequences, strains CCNWSX $0483^{\mathrm{T}}$, CCNWSX 0487, CCNWSX 0481 and CCNWSX 0457 appeared to be most closely related to Rhizobium vitis, with a mean similarity of $99.3 \%$. Phylogenetic analyses of the partial $r e c A$ and $g \ln A$ sequences supported the conclusions

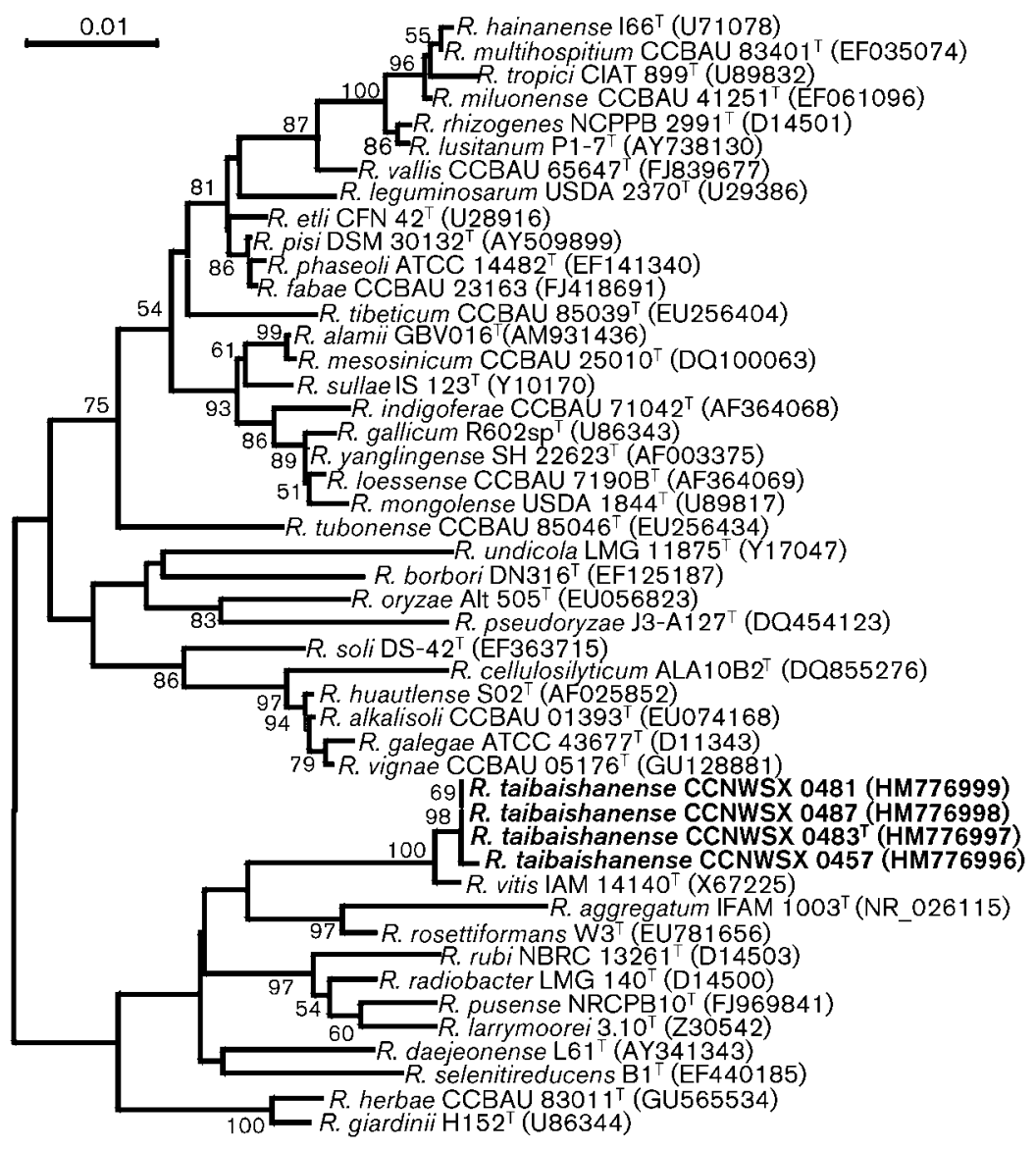

Fig. 1. Neighbour-joining tree based on $16 \mathrm{~S}$ rRNA gene sequences, showing the phylogenetic position of Rhizobium taibaishanense sp. nov. within the genus Rhizobium. Bootstrap values $(\geqslant 50 \%)$ based on 1000 resamplings are shown at branch nodes. Bar, 0.01 substitution per nucleotide position. 


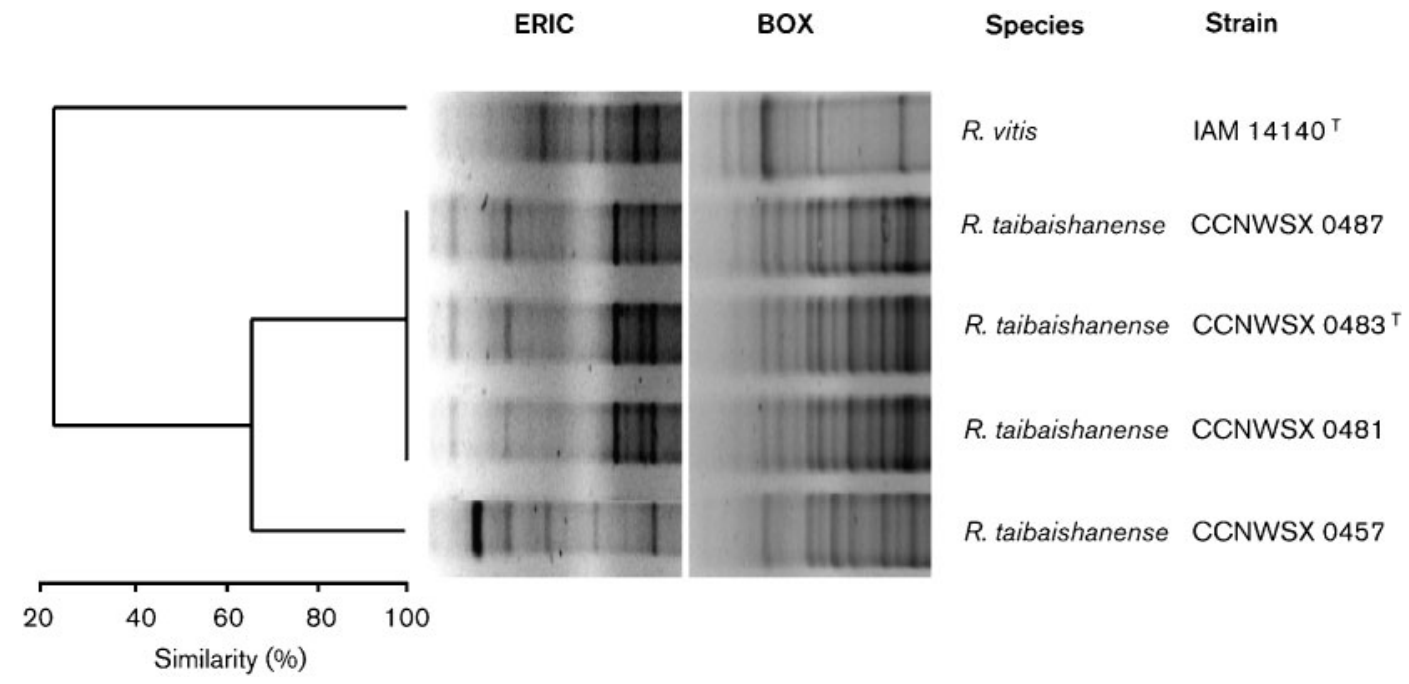

Fig. 2. The results of rep-PCR analyses showing the relationship between $R$. vitis and Rhizobium taibaishanense sp. nov. Clustering analysis based on the combined ERIC- and BOX-PCR fingerprints was performed using the UPGMA method.

drawn from the $16 \mathrm{~S}$ rRNA gene sequences (Supplementary Figs S1 and S2, available in IJSEM Online). The observed recA and $g \ln A$ gene sequences of strains CCNWSX $0483^{\mathrm{T}}$, CCNWSX 0487 and CCNWSX 0481 were identical and showed $97.8 \%(\operatorname{rec} A)$ and $98.5 \%(\ln A)$ similarities with the corresponding sequences of strain CCNWSX 0457. For recA, strain CCNWSX $0483^{\mathrm{T}}$ showed the highest sequence similarities with Rhizobium rosettiformans $\mathrm{W}^{\mathrm{T}}(86.5 \%)$ and Rhizobium rhizogenes NCPPB $2991^{\mathrm{T}}(82.8 \%)$. For $\ln A$, the strains of recognized species that appeared most closely related to CCNWSX $0483^{\mathrm{T}}$ were $R$. rhizogenes LMG $150^{\mathrm{T}}(88.9 \%)$, Ensifer adhaerens LMG $20216^{\mathrm{T}}(88.8 \%)$ and R. vitis S4 (88.5\%). The low similarities found between the $r e c A$ and $g \ln A$ gene sequences of strains CCNWSX $0483^{\mathrm{T}}$, CCNWSX 0487, CCNWSX 0481 and CCNWSX 0457 and the corresponding sequences of any recognized species indicated that the four Chinese strains represent a novel speices of the genus Rhizobium.

Rep-PCR is a useful method for differentiating closely related rhizobia and can be accurate to strain level (Gao et al., 2001; Kawaguchi et al., 2008; Laguerre et al., 2003; Menna et al., 2009). In the present study, the primers ERIC1R ( $5^{\prime}$-ATGTAAGCTCCTGGGGATTCAC- $\left.3^{\prime}\right)$ and ERIC2 (5'-AAGTAAGTGACTGGGGTGAGCG-3') were used for ERIC-PCR (Versalovic et al., 1991) while BOXAIR (5'-CTACGGCAAGGCGACGCTGACG-3') was used as the primer for BOXPCR (Versalovic et al., 1994). In these rep-PCR, each type of DNA fragment with a different electrophoretic mobility was scored as either 1 (if present) or 0 (if absent). The BioNumerics program (Applied Mathematics), with the UPGMA algorithm and the Jaccard coefficient (Sneath \& Sokal, 1973), were used for the cluster analysis. The results of the rep-PCR analysis confirmed that strains CCNWSX $0483^{\mathrm{T}}$, CCNWSX 0487, CCNWSX 0481 and CCNWSX 0457 were each different from Rhizobium vitis IAM $14140^{\mathrm{T}}$. The
rep-PCR results for strains CCNWSX $0483^{\mathrm{T}}$, CCNWSX 0487 and CCNWSX 0481 were identical, while those for strain CCNWSX 0457 indicated a similarity level of $66 \%$ with the other three strains (Fig. 2), demonstrating that the four strains were not all clones of one strain.

DNA-DNA hybridization is a useful method for identifying novel bacterial species, especially when the 16S rRNA gene sequence of the novel species has a high level of similarity with that of an established species (Graham et al., 1991). Total DNA was therefore isolated from strains CCNWSX 0483 ${ }^{\mathrm{T}}$, CCNWSX 0487, CCNWSX 0481 and CCNWSX 0457 and purified (Marmur, 1961). The DNA $\mathrm{G}+\mathrm{C}$ content was determined by the thermal denaturation method of Marmur \& Doty (1962), with Escherichia coli K12 used as the standard. The $\mathrm{G}+\mathrm{C}$ content of the four Chinese strains $(58.0-59.2 \mathrm{~mol} \%)$ fell within the range reported for the genus Rhizobium (Jordan, 1984). DNADNA relatedness was then estimated by following the thermal melting protocol of De Ley et al. (1970). Although the level of DNA-DNA relatedness among the four Chinese strains ranged from $89.04 \%$ to $96.30 \%$, that between the representative Chinese strain $\left(\right.$ CCNWSX $0483^{\mathrm{T}}$ ) and the reference strain of R. vitis (IAM $14140^{\mathrm{T}}$ ) was only $40.13 \%$ (Table 1), again indicating that strains CCNWSX $0483^{\mathrm{T}}$, CCNWSX 0487, CCNWSX 0481 and CCNWSX 0457 represent a novel species.

Cellular fatty acid profiles have been used to distinguish between species of Rhizobium and those of related genera (Tighe et al., 2000). To measure the fatty acid composition of strain CCNWSX $0483^{\mathrm{T}}$, the strain was incubated at $28{ }^{\circ} \mathrm{C}$ for $48 \mathrm{~h}$ on TY medium (Jarvis et al., 1996). The methods subsequently used for harvesting, saponification, methylation and extraction of the cellular fatty acids followed version 3.0 of the Sherlock Microbial Identification System 
Table 1. Strains used in this study and their DNA-DNA relatedness

\begin{tabular}{|c|c|c|c|c|}
\hline Strain & Geographical origin & Host plant & $\begin{array}{l}\text { DNA G+C } \\
\text { (mol\%) }\end{array}$ & 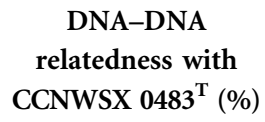 \\
\hline \multicolumn{5}{|c|}{ Rhizobium taibaishanense sp. nov. } \\
\hline CCNWSX $0483^{\mathrm{T}}$ & $\begin{array}{c}\text { Taibaishan Mountains, Shaanxi, } \\
\text { China }\end{array}$ & Kummerowia striata & 58.0 & 100 \\
\hline CCNWSX 0487 & $\begin{array}{c}\text { Taibaishan Mountains, Shaanxi, } \\
\text { China }\end{array}$ & Kummerowia striata & 58.0 & 96.30 \\
\hline CCNWSX 0481 & $\begin{array}{c}\text { Taibaishan Mountains, Shaanxi, } \\
\text { China }\end{array}$ & Kummerowia striata & 58.2 & 92.80 \\
\hline CCNWSX 0457 & Yangling, Shaanxi, China & Kummerowia striata & 59.2 & 89.04 \\
\hline Rhizobium vitis IAM $14140^{\mathrm{T}}$ & Australia & Vitis sp. & 59.8 & 40.13 \\
\hline
\end{tabular}

(MIDI, 1999). A Hewlett Packard 6890 gas chromatograph equipped with an Ultra2 capillary column $(25 \mathrm{~m} \times 0.2 \mathrm{~mm})$ and a flame-ionization detector was then used to separate the fatty acid methyl esters. For this chromatography, hydrogen was used as the carrier gas, nitrogen was the 'makeup' gas, and air was used to support the flame. Peak integration and identification were performed using the MIDI software package (Sherlock TSBA40 method and TSBA40 library; MIDI Inc.). The cellular fatty acids of strain CCNWSX $0483^{\mathrm{T}}$ were identified as $\mathrm{C}_{18: 1} \omega 7 c(65.02 \%)$, $\mathrm{C}_{16: 0}(6.47 \%), \mathrm{C}_{16: 0} \quad 3-\mathrm{OH}(3.22 \%)$, iso- $\mathrm{C}_{17: 0} 3-\mathrm{OH}$ (1.63\%), $\mathrm{C}_{18: 1} \omega 7 c$ 11-methyl $(2.31 \%), \mathrm{C}_{18: 0} \quad 3-\mathrm{OH}$ (1.09\%), $\mathrm{C}_{18: 1}$ 2-OH (1.50\%), $\mathrm{C}_{19: 0}$ cyclo $\omega 8 c(6.18 \%)$ and $\mathrm{C}_{19: 0}$ 10-methyl (1.66\%), with three summed features (Supplementary Table S1), indicating that the strain should be assigned to the genus Rhizobium (Tighe et al., 2000). Strain CCNWSX $0483^{\mathrm{T}}$ differed from recognized species of the genus Rhizobium in its lack of detectable $\mathrm{C}_{18: 0}$ and $\mathrm{C}_{20: 3} \omega 6,9,12 c$, its higher levels of iso- $\mathrm{C}_{17: 0} 3-\mathrm{OH}$, and its possession of $\mathrm{C}_{18: 0} 3-\mathrm{OH}$.

The phenotypic features of strains CCNWSX $0483^{\mathrm{T}}$, CCNWSX 0487, CCNWSX 0481 and CCNWSX 0457 were also compared with those of $R$. vitis IAM $14140^{\mathrm{T}}$, using the methods described by Gao et al. (1994). Twenty-four different carbon sources and 15 types of nitrogen source were tested. Resistance to chloramphenicol, lincomycin, azithromycin, kanamycin, amikacin sulfate, streptomycin sulfate, ampicillin and benzylpenicillin sodium, each at concentrations of $300,100,50$ and $5 \mu \mathrm{g} \mathrm{ml}^{-1}$ in YMA, was also investigated. The temperature range for growth was determined by incubating cultures on YMA at 4,40 and $60{ }^{\circ} \mathrm{C}$. The effect of $\mathrm{pH}$ on growth was explored using YMA at final $\mathrm{pH}$ values of 4.0, 5.0, 9.0, 10.0, 11.0 and 12.0 and the method of Moffett \& Colwell (1968). Salt tolerance was studied in YMA containing 1-6\% (w/v) $\mathrm{NaCl}$. Dye and chemical resistance was investigated with methyl orange, methyl red, methylene blue, neutral red, Congo red, malachite green, bromothymol blue, sodium deoxycholate and $\mathrm{NaNO}_{2}$, each at concentrations of $1 \%$ and $2 \%(\mathrm{w} / \mathrm{v})$ in YMA. Reactions in litmus milk, alkali production from malonic acid, utilization of citrate and production of 3-ketolactose were examined by the methods of Moore et al. (1988). Indole production, reactions in the methyl red and Voges-Proskauer tests, hydrolysis of starch, gelatin and Tween 80 , catalase, urease and oxidase activities, reduction of nitrate and nitrite, and hydrogen sulphide production from cysteine were also determined, as described by Smibert \& Krieg (1994). Distinctive phenotypic characteristics of strains CCNWSX $0483^{\mathrm{T}}$, CCNWSX 0487, CCNWSX 0481 and CCNWSX 0457 and the type strains of the phylogenetically closest species are shown in Table 2. Strains CCNWSX $0483^{\mathrm{T}}$, CCNWSX 0487, CCNWSX 0481 and CCNWSX 0457 each differed from $R$. vitis in their ability to utilize $\beta$-naphthyl acetate, hydrolyse gelatin, peptonize and reduce litmus milk and grow at $40{ }^{\circ} \mathrm{C}$, and in their inability to utilize (-)-L-sorbose and citrate, produce alkali from litmus milk, and grow in the presence of $2 \%(\mathrm{w} / \mathrm{v}) \mathrm{NaCl}$.

Attempts were made to amplify intragenic fragments of any nodA, nifH and virC genes in strains CCNWSX $0483^{\mathrm{T}}$, CCNWSX 0487, CCNWSX 0481 and CCNWSX 0457, to see if the strains harboured the sym and vir genes that can induce the formation of root nodules and plant tumours, respectively. Amplification of the nodA fragment (Haukka et al., 1998) was based on the primers nodA-F1 ( $5^{\prime}$-TGCRGTGGARDCTRYGCTGGGAAA-3') and nodA-R2 (5'-GGNCCGTCRTCRAASGTCARGTA- $3^{\prime}$ ). The primers nifH40F (5'-GGNATCGGCAAGTCSACSAC- $\left.3^{\prime}\right)$ and nifH817R (5'TCRAMCAGCATGTCCTCSAGCTC-3') were used for the amplification of the nifH fragment (Vinuesa et al., 2005), whereas amplification of the virC fragment (Sawada et al., 1995) was based on VCF (5'-ATCATTTGTAGCGACT-3') and VCR (5'-AGCTCAAACCTGCTTC-3'). Although the expected amplicons were produced when the three different PCR were run with the DNA of $R$. leguminosarum USDA $2370^{\mathrm{T}}$ (nodA and nifH amplifications) or R. vitis IAM $14140^{\mathrm{T}}$ ( $\operatorname{vir} C$ amplifications) used as positive controls, no amplicons were detected when the template DNA came from strains CCNWSX $0483^{\mathrm{T}}$, CCNWSX 0487, CCNWSX 0481 or CCNWSX 0457.

To assess their symbiotic potential, strains CCNWSX $0483^{\mathrm{T}}$, CCNWSX 0487, CCNWSX 0481, CCNWSX 0457 
Table 2. Major characteristics that distinguish Rhizobium taibaishanense sp. nov. from the closest recognized species, R. vitis

Taxa: $1, R$. vitis IAM $14140^{\mathrm{T}} ; 2, R$. taibaishanense sp. nov. CCNWSX 0487; 3, R. taibaishanense sp. nov. CCNWSX 0483 ${ }^{\mathrm{T}} ; 4, \quad R$. taibaishanense sp. nov. CCNWSX 0481; 5, R. taibaishanense sp. nov. CCNWSX 0457. +, Positive; -, negative.

\begin{tabular}{|c|c|c|c|c|c|}
\hline Characteristic & 1 & 2 & 3 & 4 & 5 \\
\hline \multicolumn{6}{|l|}{ Substrates used as sole carbon source: } \\
\hline (-)-L-Sorbose & + & - & - & - & - \\
\hline$\beta$-Naphthyl acetate & - & + & + & + & + \\
\hline Sodium succinate & + & - & + & + & + \\
\hline \multicolumn{6}{|l|}{ Substrates used as sole nitrogen source: } \\
\hline L-Alanine & + & - & + & + & + \\
\hline L-Cysteine & + & - & + & + & - \\
\hline DL- $\alpha$-Aminopropionic acid & + & - & + & + & - \\
\hline L-Tyrosine & + & - & + & + & + \\
\hline \multicolumn{6}{|l|}{ Antibiotic resistance: } \\
\hline Benzylpenicillin sodium $\left(50 \mu \mathrm{g} \mathrm{ml}^{-1}\right)$ & + & + & + & + & - \\
\hline Benzylpenicillin sodium $\left(100 \mu \mathrm{g} \mathrm{ml}^{-1}\right)$ & + & + & + & + & - \\
\hline Benzylpenicillin sodium $\left(300 \mu \mathrm{g} \mathrm{ml}^{-1}\right)$ & + & + & + & - & - \\
\hline Ampicillin $\left(50 \mu \mathrm{g} \mathrm{ml}^{-1}\right)$ & + & - & + & + & - \\
\hline Streptomycin sulfate $\left(50 \mu \mathrm{g} \mathrm{ml}^{-1}\right)$ & + & - & + & + & - \\
\hline Streptomycin sulfate $\left(100 \mu \mathrm{g} \mathrm{ml}^{-1}\right)$ & - & - & + & - & - \\
\hline Streptomycin sulfate $\left(300 \mu \mathrm{g} \mathrm{ml}^{-1}\right)$ & - & - & + & - & - \\
\hline Amikacin sulfate $\left(5 \mu \mathrm{g} \mathrm{ml}^{-1}\right)$ & + & - & + & + & + \\
\hline \multicolumn{6}{|l|}{ Tolerance to: } \\
\hline Malachite green (1\%) & + & - & + & + & - \\
\hline $\mathrm{NaCl}(1 \%)$ & + & + & + & + & - \\
\hline $\mathrm{NaCl}(2 \%)$ & + & - & - & - & - \\
\hline $\mathrm{NaCl}(3 \%)$ & + & - & - & - & - \\
\hline \multicolumn{6}{|l|}{ Growth at: } \\
\hline $\mathrm{pH} 4$ & + & + & - & + & + \\
\hline $40{ }^{\circ} \mathrm{C}$ & - & + & + & + & + \\
\hline Hydrolysis of Tween 80 & - & - & - & - & + \\
\hline Gelatin liquefaction & - & + & + & + & + \\
\hline Citrate utilization & - & + & + & + & + \\
\hline Litmus milk alkali production & + & - & - & - & - \\
\hline Litmus milk peptonization & - & + & + & + & + \\
\hline Reduction of litmus milk & - & + & + & + & + \\
\hline
\end{tabular}

and, as a positive control, the symbiotic strain Ensifer kummerowiae CCBAU $71714^{\mathrm{T}}$ (which was isolated from K. stipulacea) were each inoculated onto seedlings grown in pots filled with vermiculite that had been moistened with N-free plant nutrient solution (Vincent, 1970). The inoculated plants were $K$. striata (i.e. the host of origin of strains CCNWSX 0483 ${ }^{\mathrm{T}}$, CCNWSX 0487, CCNWSX 0481 and CCNWSX 0457) and two species of leguminous plant that often coexist with $K$. striata in north-western China: Melilotus officinalis and Medicago sativa. The inoculated plants were allowed to grow for 1 month before being checked for signs of root nodulation. Although all three plant species inoculated with the positive control developed pink nodules, no nodules were detected on any of the other plants.
The ability of strains CCNWSX $0483^{\mathrm{T}}$, CCNWSX 0487, CCNWSX 0481, CCNWSX 0457 and, as a positive control, the tumour-inducing $R$. vitis IAM $14140^{\mathrm{T}}$ to produce crown galls was investigated by inoculating 4-week-old tomato seedlings and 3-week-old sunflower seedlings (Moore et al., 2001). After the plants were left to grow for 1 month, only those inoculated with the positive control were found to have developed crown galls.

The results of the present study indicate that strains CCNWSX $0483^{\mathrm{T}}$, CCNWSX 0487, CCNWSX 0481 and CCNWSX 0457 represent a novel species related to, but distinct from, $R$. vitis, for which we propose the name Rhizobium taibaishanense sp. nov.

\section{Description of Rhizobium taibaishanense sp. nov.}

Rhizobium taibaishanense (tai.bai.shan.en'se. N.L. neut. adj. taibaishanense of or belonging to the Taibaishan Mountains in the Shaanxi province of China, where the bacterium was isolated).

The morphology of the cells and colonies is as described for the genus Rhizobium. Produces acid on YMA and uses sodium pyruvate, sodium malonate, D-xylose, galactose, D-fructose, sodium propionate, L-arabinose, raffinose, Dribose, rhamnose, sodium hippurate, $\beta$-naphthyl acetate, $\alpha$-naphthalene acetic acid, mannose, maltose, trisodium citrate, sodium acetate, glucose, sucrose, lactose, sodium tartrate and inositol as sole carbon source; some strains can also use sodium succinate but none of those tested can use (-)-L-sorbose or starch. L-Cystine, L-methionine, L-lactamine, L-glutamic acid, L-asparagine, L-threonine, L-leucine, L-adenine, L-arginine and L-phenylalanine are used as sole nitrogen sources; some strains can also use L-cysteine, DL- $\alpha$-aminopropionic acid, L-tyrosine and Lalanine but none of those tested can utilize DL-histidine. Grows on YMA medium at 4 and $40{ }^{\circ} \mathrm{C}$, at $\mathrm{pH} 12.0$, and with $1 \% \mathrm{NaCl}$ (except strain CCNWSX 0457), $0.2 \%$ methyl orange, $0.2 \%$ methyl red, $0.2 \%$ neutral red, $0.2 \%$ Congo red, $0.2 \%$ bromothymol blue, $0.2 \%$ sodium deoxycholate, $0.2 \% \mathrm{NaNO}_{2}, 300 \mu \mathrm{g}$ chloramphenicol $\mathrm{ml}^{-1}$, or $300 \mu \mathrm{g}$ lincomycin ml$l^{-1}$. However, it is sensitive to azithromycin at $5 \mu \mathrm{g} \mathrm{ml}^{-1}$, kanamycin at $50 \mu \mathrm{g} \mathrm{ml}^{-1}$ and amikacin sulfate at $50 \mu \mathrm{g} \mathrm{ml}^{-1}$. Does not produce 3ketolactose or $\mathrm{H}_{2} \mathrm{~S}$, but does produce alkali from citric and malonic acids. Produces catalase and oxidase, reduces nitrate and nitrite, hydrolyses gelatin, and peptonizes and reduce litmus milk. Gives negative results in methyl red, Voges-Proskauer and indole tests. Of the tested strains, only CCNWSX 0457 can utilize Tween 80 .

The type strain, CCNWSX $0483^{\mathrm{T}}\left(=\right.$ ACCC $14971^{\mathrm{T}}=$ HAMBI $3214^{\mathrm{T}}$ ), was isolated from a root nodule of Kummerowia striata grown in the Taibaishan Mountains, in the Shaanxi province of China. The DNA G+C content of the type strain is $58.0 \mathrm{~mol} \%$. 


\section{Acknowledgements}

This work was supported by the 973 Project of China (2010CB126502), National Science Foundation of China (30970003, 30900215 and 30630054), International Science and Technology Cooperation Program of China (2010DFA91930), and the Key Laboratory of Protection and Utilization of Biological Resources in Tarim Basin, Xinjiang Production and Construction Group (BRZD1002). We are grateful to Dr Kristina Lindström and Professor Ruibo Jiang for the deposition of the type strain in their culture collections.

\section{References}

Allen, O. N. \& Allen, E. K. (1981). The Leguminosae: A Source Book of Characteristics, Uses and Nodulation. Madison, WI: The University of Wisconsin Press.

Altschul, S. F., Gish, W., Miller, W., Myers, E. W. \& Lipman, D. J. (1990). Basic local alignment search tool. J Mol Biol 215, 403-410.

Conn, H. J. (1942). Validity of the genus Alcaligenes. J Bacteriol 44, 353-360.

Cui, G. L., Xie, R. M., Yue, J. J., Liang, J. Q., Duan, X. D., Fan, L. M. \& Wei, G. H. (2010). Diversity and phylogeny of rhizobia isolated from Kummerowia in northwest of China. J Agric Biotechnol 18, 867-875 (in Chinese).

De Ley, J., Cattoir, H. \& Reynaerts, A. (1970). The quantitative measurement of DNA hybridization from renaturation rates. Eur $J$ Biochem 12, 133-142.

Farrand, S. K., Van Berkum, P. B. \& Oger, P. (2003). Agrobacterium is a definable genus of the family Rhizobiaceae. Int J Syst Evol Microbiol 53, 1681-1687.

Gao, J. L., Sun, J. G., Li, Y., Wang, E. T. \& Chen, W. X. (1994). Numerical taxonomy and DNA relatedness of tropical rhizobia isolated from Hainan province, China. Int J Syst Bacteriol 44, 151-158.

Gao, J. L., Terefework, Z., Chen, W. X. \& Lindström, K. (2001). Genetic diversity of rhizobia isolated from Astragalus adsurgens growing in different geographical regions of China. J Biotechnol 91, 155-168.

Gaunt, M. W., Turner, S. L., Rigottier-Gois, L., Lloyd-Macgilp, S. A. \& Young, J. P. W. (2001). Phylogenies of atpD and recA support the small subunit rRNA-based classification of rhizobia. Int J Syst Evol Microbiol 51, 2037-2048.

Graham, P. H., Sadowsky, M. J., Keyser, H. H., Barnet, Y. M., Bradley, R. S., Cooper, J. E., De Ley, D. J., Jarvis, B. D. W., Roslycky, E. B. \& other authors (1991). Proposed minimal standards for the description of new genera and species of root- and stem-nodulating bacteria. Int J Syst Bacteriol 41, 582-587.

Haukka, K., Lindström, K. \& Young, J. P. W. (1998). Three phylogenetic groups of nodA and nifH genes in Sinorhizobium and Mesorhizobium isolates from leguminous trees growing in Africa and Latin America. Appl Environ Microbiol 64, 419-426.

Jarvis, B. D. W., Sivakumaran, S., Tighe, S. W. \& Gillis, M. (1996). Identification of Agrobacterium and Rhizobium species based on cellular fatty acid composition. Plant Soil 184, 143-158.

Jordan, D. C. (1984). Genus I. Rhizobium Frank 1889, $338^{\mathrm{AL}}$. In Bergey's Manual of Systematic Bacteriology, vol. 1, pp. 235-242. Edited by N. R. Krieg \& J. G. Holt. Baltimore: Williams \& Wilkins.

Jukes, T. H. \& Cantor, C. R. (1969). Evolution of protein molecules. In Mammalian Protein Metabolism, pp. 21-132. Edited by H. N. Munro. London: Academic Press.

Kawaguchi, A., Sawada, H. \& Ichinose, Y. (2008). Phylogenetic and serological analyses reveal genetic diversity of Agrobacterium vitis strains in Japan. Plant Pathol 57, 747-753.
Kersters, K., De Ley, J., Sneath, P. H. A. \& Sackin, M. (1973). Numerical taxonomic analysis of Agrobacterium. J Gen Microbiol 78, 227-239.

Kimura, M. (1983). The Neutral Theory of Molecular Evolution. Cambridge: Cambridge University Press.

Kumar, S., Nei, M., Dudley, J. \& Tamura, K. (2008). MEGA: a biologistcentric software for evolutionary analysis of DNA and protein sequences. Brief Bioinform 9, 299-306.

Laguerre, G., Louvrier, P., Allard, M. R. \& Amarger, N. (2003). Compatibility of rhizobial genotypes within natural populations of Rhizobium leguminosarum biovar viciae for nodulation of host legumes. Appl Environ Microbiol 69, 2276-2283.

Marmur, J. (1961). A procedure for the isolation of deoxyribonucleic acid from micro-organisms. J Mol Biol 3, 208-218.

Marmur, J. \& Doty, P. (1962). Determination of the base composition of deoxyribonucleic acid from its thermal denaturation temperature. J Mol Biol 5, 109-118.

Menna, P., Pereira, A. A., Bangel, E. V. \& Hungria, M. (2009). rep-PCR of tropical rhizobia for strain fingerprinting, biodiversity appraisal and as a taxonomic and phylogenetic tool. Symbiosis 48, 120-130.

MIDI (1999). Sherlock Microbial Identification System Operating Manual, version 3. Newark, DE: MIDI Inc.

Moffett, M. L. \& Colwell, R. R. (1968). Adansonian analysis of the Rhizobiaceae. J Gen Microbiol 51, 245-266.

Moore, L. W., Kado, C. I. \& Bouzar, H. (1988). Agrobacterium. In Laboratory Guide for Identification of Plant Pathogenic Bacteria, 2nd edn, pp. 16-36. Edited by N. W. Schaad. St Paul, MN: American Phytopathology Society.

Moore, L. W., Bouzar, H. \& Burr, T. (2001). Agrobacterium. In Laboratory Guide for Identification of Plant Pathogenic Bacteria, 3rd edn, pp. 17-35. Edited by N. W. Schaad, J. B. Jones \& W. Chun. St Paul, MN: American Phytopathology Society.

Moulin, L., Béna, G., Boivin-Masson, C. \& Stępkowski, T. (2004). Phylogenetic analyses of symbiotic nodulation genes support vertical and lateral gene co-transfer within the Bradyrhizobium genus. Mol Phylogenet Evol 30, 720-732.

New Medicine College of Jiangsu (1977). Dictionary of Chinese Traditional Medicine, Part 1. Shanghai: Shanghai People Publishing Company.

Rzhetsky, A. \& Nei, M. (1993). Theoretical foundation of the minimum-evolution method of phylogenetic inference. Mol Biol Evol 10, 1073-1095.

Saitou, N. \& Nei, M. (1987). The neighbor-joining method: a new method for reconstructing phylogenetic trees. Mol Biol Evol 4, 406-425.

Sawada, H., leki, H. \& Matsuda, I. (1995). PCR detection of Ti and Ri plasmids from phytopathogenic Agrobacterium strains. Appl Environ Microbiol 61, 828-831.

Smibert, R. M. \& Krieg, N. R. (1994). Phenotypic characterization. In Methods for General and Molecular Bacteriology, pp. 607-654. Edited by P. Gerhardt, R. G. E. Murray, W. A. Wood \& N. R. Krieg. Washington, DC: American Society for Microbiology.

Sneath, P. H. A. \& Sokal, R. B. (1973). Numerical Taxonomy. The Principles and Practice of Numerical Classification. San Francisco: W. H. Freeman and Co.

Swofford, D. L. (1993). PAUP: Phylogenetic analysis using parsimony, version 3.1.1. Champaign, IL: Illinois Natural History Survey.

Tajima, F. \& Nei, M. (1984). Estimation of evolutionary distance between nucleotide sequences. Mol Biol Evol 1, 269-285.

Tamura, K., Nei, M. \& Kumar, S. (2004). Prospects for inferring very large phylogenies by using the neighbor-joining method. Proc Natl Acad Sci U S A 101, 11030-11035. 
Tan, Z. Y., Xu, X. D., Wang, E. T., Gao, J. L., Martinez-Romero, E. \& Chen, W. X. (1997). Phylogenetic and genetic relationships of Mesorhizobium tianshanense and related rhizobia. Int J Syst Bacteriol 47, 874-879.

Thompson, J. D., Higgins, D. G. \& Gibson, T. J. (1994). CLUSTAL W: improving the sensitivity of progressive multiple sequence alignment through sequence weighting, position-specific gap penalties and weight matrix choice. Nucleic Acids Res 22, 4673-4680.

Tighe, S. W., de Lajudie, P., Dipietro, K., Lindström, K., Nick, G. \& Jarvis, B. D. W. (2000). Analysis of cellular fatty acids and phenotypic relationships of Agrobacterium, Bradyrhizobium, Mesorhizobium, Rhizobium and Sinorhizobium species using the Sherlock Microbial Identification System. Int J Syst Evol Microbiol 50, 787-801.

Turner, S. L. \& Young, J. P. W. (2000). The glutamine synthetases of rhizobia: phylogenetics and evolutionary implications. Mol Biol Evol 17, 309-319.

Versalovic, J., Koeuth, T. \& Lupski, J. R. (1991). Distribution of repetitive DNA sequences in eubacteria and application to fingerprinting of bacterial genomes. Nucleic Acids Res 19, 6823-6831.

Versalovic, J., Schneider, M., de Bruijn, F. J. \& Lupski, J. R. (1994). Genomic fingerprinting of bacteria using repetitive sequence-based polymerase chain reaction. Methods Mol Cell Biol 5, 25-40.

Vincent, J. M. (1970). A Manual for the Practical Study of Root Nodule Bacteria. Oxford: Blackwell Scientific.
Vinuesa, P., Silva, C., Lorite, M. J., Izaguirre-Mayoral, M. L., Bedmar, E. J. \& Martínez-Romero, E. (2005). Molecular systematics of rhizobia based on maximum likelihood and Bayesian phylogenies inferred from rrs, atpD, recA and nifH sequences, and their use in the classification of Sesbania microsymbionts from Venezuelan wetlands. Syst Appl Microbiol 28, 702-716.

Wang, E. T., van Berkum, P., Beyene, D., Sui, X. H., Dorado, O., Chen, W. X. \& Martínez-Romero, E. (1998). Rhizobium huautlense sp. nov., a symbiont of Sesbania herbacea that has a close phylogenetic relationship with Rhizobium galegae. Int J Syst Bacteriol 48, 687-699.

Woese, C. R., Stackebrandt, E., Weisburg, W. G., Paster, B. J., Madigan, M. T., Fowler, V. J., Hahn, C. M., Blanz, P., Gupta, R. \& other authors (1984). The phylogeny of purple bacteria: the alpha subdivision. Syst Appl Microbiol 5, 315-326.

Yoo, H. H., Kim, T., Ahn, S., Kim, Y. J., Kim, H. Y., Piao, X. L. \& Park, J. H. (2005). Evaluation of the estrogenic activity of Leguminosae plants. Biol Pharm Bull 28, 538-540.

Young, J. M., Kuykendall, L. D., Martínez-Romero, E., Kerr, A. \& Sawada, H. (2001). A revision of Rhizobium Frank 1889, with an emended description of the genus, and the inclusion of all species of Agrobacterium Conn 1942 and Allorhizobium undicola de Lajudie et al. 1998 as new combinations: Rhizobium radiobacter, $R$. rhizogenes, R. rubi, R. undicola and R. vitis. Int J Syst Evol Microbiol 51, 89-103. 